\title{
Impact of Corruption on Exchange Rate: Empirical Evidence from Panel Data
}

\author{
Ikramuddin Junejo $^{1}$, Jan Muhammad Sohu ${ }^{2}$, Farhan Hussain ${ }^{3}$
}

\begin{abstract}
This study examines the economic cost of exchange rate. Pakistan has been facing serious issue in regard of exchange rate and this fluctuations impact on various economic indicators or variables. The overall exchange rate value is being depreciated since 2008, it started from Rs 60 against one dollar and recently it reached to Rs, 160 that are equal to one dollar. Corruption has been one of the major problems faced by the countries especially that of developing countries like India and Pakistan and has affected their economy badly due to reliance of both countries on dollar and heavy imports. Time series panel data from 2002-2016 has been used for analysis, it has two cross-sections Pakistan and India. Data is collected from various sources that include Asian Development Bank, Transparency International US and World Economic Indicators. Exchange rate in Pak rupees and Ind rupees, corruption perception index in percentage and foreign borrowings in both Pak rupees and Ind rupees' variables are taken for analysis. Data will be analyzed through statistical techniques which comprises panel unit root test and panel regression analysis in E-views version 7.

Based on predictable results, all studied variables such as corruption perception index and foreign borrowings are found to have significant and positive impact on real exchange rate. In previous studies research scholars investigated overall exchange rate impact on GDP of any economy. This study gives insight into real exchange rate impact on government department corruption of both countries Pakistan and India. This study can be extended to other less developed countries which are also facing problem of exchange rate in their respective countries.
\end{abstract}

Keywords: Exchange rate, Corruption perception index, Unit root test

JEL-Classification: D73, D51, E43, F10

\section{Introduction}

Currency exchange rate crisis occurs when microeconomic as well as macroeconomic fundamentals experience vulnerabilities. Higher borrowing coupled with higher

${ }^{1}$ Department of Management Sciences, SZABIST Hyderabad campus, Sindh

${ }^{2}$ Ph.D. Management Sciences and Engineering, Jiangsu University, Zhenjiang China

${ }^{3}$ Department of Management Sciences, SZABIST Karachi Campus

OPEN ACCSS This work is Licensed under a Creative Commons Attribution-Noncommercial 4.0 International License c) (7)


corruption perception index affects exchange rate fluctuations. Asian crisis confirms it. According to Radelet and Sach (1998), many observers criticized widespread corruption and crony capitalism as a root cause for financial crisis. Mc Kinnon and Phil (1997, 1999) analyzed the Asian crisis as the "over borrowing syndrome". Corruption along with lack of transparency and excessive borrowings were thought to be the fundamental causes of exchange rate crisis. Wei and Wu (2001), proposed that corruption may affect the country's structural composition of capital inflows in a way that country faces a currency crisis internally, that can be widened by a sudden reversal international capital flow.

Ghosh and Ghosh (2002), findings showed that countries with poor governance in public sector is much likely to have exchange rate crisis. Eichengreen and Rose (1999), analyzed the impact of corruption; they found that it discourages creditors and Foreign Direct Investment (FDI). FDI suffers more. It creates a shift in composition of capital inflows over FDI. Corruption, nepotism creates hindrances for FDI, international investors need to pay bribery. They need to deal with corrupt bureaucrats, hence the cost of doing business rises. This is one of the reason that exchange rate does not stable due less FDI and foreign currency reserves engulfed by creeping corruption and external borrowings. Same is the case with Pakistan and India. Countries with high level of corruption indices face issues of FDI in their country. Developing countries face this menace in multifaceted forms. Higher debt accumulations/ higher borrowings affect many economic indicators and curb the curve down of economic growth. Foreign exchange sharply declines in line with higher debt accumulations. All these problems have negatively affected on economic growth of these two countries.

The Concept of CPI (corruption perception index) is related to foreign exchange rate fluctuation. Transparency international is global non-governmental organization which publishes CPI, aimed at combating corruption. It is used as an indicator to check the country's' credibility. Higher the level of CPI, higher the chances of currency crisis. It has major impact on FDI. Additionally, every country is a member of some international trade organization. In 21 st century, the development /economic models around the world are interdependent on between more than two countries. Therefore, exchange rate does not only create chaos in one country's economy, but it affects the whole region or at least other member of the same trade organization. Moreover, membership in international financial and trade organizations might have a reasonable impact on country credibility. However, when checking for the sample countries membership, each country is found to be a member of some international organization. Nevertheless, membership in the European Union was included in to this study in order to analyze the impacts of being an international organization member on country credibility.

Sukkur IBA Journal of Management and Business - SIJMB | Volume 6 No. 1 January - June 2019 @ Sukkur IBA University 


\subsection{Objectives:}

- To measure the impact of corruption perception on exchange rate of Pakistan and India.

- To measure the impact of foreign borrowings on exchange rate of Pakistan and India.

\subsection{Research Questions:}

- Is there any impact of corruption perception index on exchange rate of Pakistan and India?

- Do foreign borrowings effect on exchange rate of Pakistan and India?

\subsection{Theoretical and Conceptual framework:}

An economic theory suggests that if the money borrowed by a country is utilized is efficient and effective manner in the productive investment purpose that has trickledown effect in the economic growth of that country. On the other hand, if the borrowed money is not used properly, due to corruption can badly hit the economy of any country, where exchange rate rises along with inflation in multifarious sectors. This situation is explained by overhang theory. This theory states that if the borrowed money level, exceeds, above the capacity of country to repay it, then, an expected default of country may signal the local and foreign investors to draw their money back. This creates the bottlenecks situations for a country, where borrowings creates dramatic shift in exchange rate. These foreign borrowings negatively affect the economic growth. For the sake of repayments of debt, domestic output is increases via additional taxes, which again creates inflation. Figure 1 depicts the relationship between the constructs of current study.

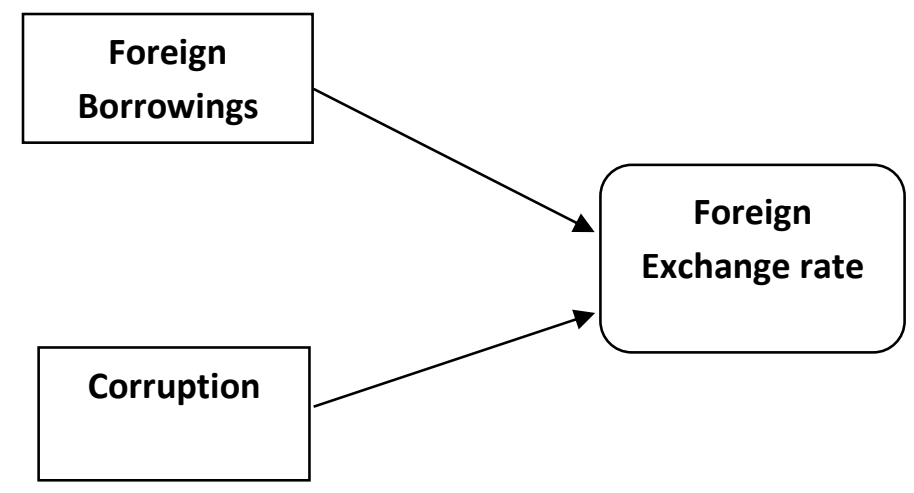

Figure 1: Relationship between the constructs of current study

The rest of this paper follows the structure as: The following section provides review of background of previous related studies literature. Section three discusses the

Sukkur IBA Journal of Management and Business - SIJMB | Volume 6 No. 1 January - June 2019 @ Sukkur IBA University 
methodological issues, section four presents observed results. Finally, last section, section five includes some final remarks and future extension proposal / the way forward.

\section{Literature Review \& Hypothesis Developments}

Literature of currency crisis is attributed to (Krugman, 2002) classic paper. His work was further simplified in comprehensive by (Flood and Garber 2008, Agenor et al. 2011). First generation crisis models were based on exhaustible literature resource. These crises occurred because of adverse macroeconomic policy, poorly associated with exchange rate. Models failed. European Monetary System (EMS) and in Mexico crises occurred in same year. Earlier model couldn't justify the reason. Followed by the previous events, 2nd generation model was developed (Obstfeld 1994). This model specifically focused on government policy an exchange rate and other objectives. Again the model failed. Asian crisis of 1997-98 put a question mark on the existing model. Third generation model was developed. Krugman (1999), identified two post approaches to this crisis. The first approach namely moral hazard approach represented (Krugman, 1999) and over borrowing syndrome (Kinnon \& Phill, 1999). Corruption coupled with lack of transparency were perceived to be the eventual cause engulfed by the over borrowing throughout the economy.

\subsection{Currency Exchange Rate}

According to financial dictionary Currency Exchange rate is defined as the value of one currency in terms of in another value e.g. the price at which Pakistani rupee is exchanged for another currency say dollar is exchange rate. For Uddin, Rehman and Quaosa (2014) exchange rate is one of the factors through which currencies can be converted. It is as important as the other factors are such as inflation, interest rate etc. a country's economic position can be gauged by its exchange rates due to its influence on the performance of economies especially that of developing countries because they heavily rely on dollar for their imports. It is analyzed that if corruption has positive effect on yield/real exchange rate, a tight peg routine can increase endured humiliation. Nevertheless, if defilement (corruption) has negatively affects yield/real exchange rate, attached exchange rate routine will decrease capacity of suffered corruption (Popkova, 2010)

\subsection{Corruption \& Exchange Rate}

Corruption has been a pervasive phenomenon for many developing and developed countries, running as an inseparable unit with higher rates of swelling and ambitious spending policies. Corruption is just a single marker of bad institutions. Connection of corruption with other, resource rich countries are frequently described by large amounts of corruption and lease chasing. Specialists discussed an alternate focus but and found proof that there is u-shaped connection between exchange rate and

Sukkur IBA Journal of Management and Business - SIJMB | Volume 6 No. 1 January - June 2019 @ Sukkur IBA University 
corruption (Hussain, Sabir, \& Meo, 2017). It is analyzed that the effect of corruption on the decision of genuine exchange rate since I surmise that the association between money related approach, financial strategy and debasement has not been adequately considered. It very well demonstrated that if corruption positively affects yield, a tight peg routine to a low expansion nation, which adapts to issues of financial validity, could increment endured corruption (Popkova, 2010). Menace like corruption may have significant affect in composition of if capital inflows for a particular country in a way that it makes more vulnerable for international creditors to shift their expectations (Wei and Wu 2002). In a nut shell, corruption refers to the degree to which firms or sometimes local citizens bribe the officials in their communications to achieve their objectives specifically (for licenses, permits, loans, and so forth). However, in general we perceive corruption more broadly as an indicator for poor governance, which is not only limited to bureaucratic corruption, but to deviations from arbitrary government regulations and rule of law. In, fact the two said hypothesis are interlinked. The degree of corruption in a nation state may affect the composition of inflows in a way that it makes susceptible to foreign creditors to change their perception and shift their capital to another nation state. Importance of compositions inflows, outflows, was highlighted in exchange rate crisis of Russia, East Asia and Latin America. Multiple studies have been made on the correlations between capital inflows a currency crisis. They showed the positive relations. (Wei, S. J., \& Wu, Y. (2002). Supporting studies starts with (Frakel \& Rose 1996, Sachs, Rodrik and Velasco 1999). Based on above previous studies the alternative hypothesis has been developed:

\section{H1: There is significant impact of corruption on real exchange rate}

\subsection{Foreign Borrowings \& Exchange Rate}

Cambridge and business dictionary defines foreign borrowing as the amount of loan borrowed by any government to government or from any international organization. Borrowings can be directly government to or indirectly because of negative BOT. Economic theories by famous economist around world suggest that countries borrow money, in difficult economic conditions of their country in general and in specific to maintain the balance of trade (BOT) or for the settlement of EXIM (export-import) bill. This can be seen in the recent crisis of Pakistan. It is facing the challenges for trade bill settlement. According to official source by government of Pakistan, it has approached the IMF for funds to settle the trade deficit. Dollar reserves are at lowest level in history of last four years (Dawn, Oct., 5, 2018). Therefore deteriorating reserves has put pressure on foreign exchange rate of Pakistan in particular.

In these tough economic conditions, Pakistan is looking for the options to borrow the funds to deal with economic challenges. If the funds borrowed are not utilized in efficient and effective manner and for productive investment or managing BOT, then it can have negative result on the economic growth and economy and on exchange rate. But on other hand if they used for productive investment purpose the results will

Sukkur IBA Journal of Management and Business - SIJMB | Volume 6 No. 1 January - June 2019 @ Sukkur IBA University 
be altogether. The recent corruption cases against political leaders is an example of how their corruption has contributed in the appreciation of dollar and devaluation of Pakistani rupee, which has affected the whole economic cycle of the country. Economy will rise with economic growth, and exchange rate would remain stable to attract foreign direct investment in country. The external debt thus accumulates with the passage of time. There comes a situation where it can have negative impact on economy. Irony of debt can be explained by overhang theory (Rabia \& Malick 2012). When the amount of debt accumulated crosses the threshold level of any country's repayment capacity, may signal the default of economy in the eyes of investors to draw back their money; this will lower FDI in country and will hit the economy negatively. This study specifically analyzes the impact of foreign borrowings and corruption on foreign exchange rate in Pakistan. One of the indicators of economic growth of any country is gross domestic product (GDP). Investment, corruption, foreign borrowing / debt has major influence on GDP of a country (Giancarlo et al. 1999). Therefore, the model of this study test the influence of corruption and foreign borrowings on exchange rate, which directly or indirectly have major impact on economic growth. Due to the corruption, Pakistan can possibly fabricate a prosperous economy, decrease neediness fundamentally and give the social living, training, and environmental benefits its populace needs. Nonetheless, accessible proof shows that these assets have not been sensibly used to address the issue of the populace as far as human capital improvement due to abnormal state of corruption in the nation. The primary point of this investigation is to look at the effect of corruption on monetary development. The investigation utilized co-combination test, granger causality test and standard minimum square (OLS) technique. We utilized total national output (Gross domestic product) as intermediary for corruption and corruption list as intermediary for corruption. The exact investigation uncovers that there is a long run connection between the dimension of corruption and monetary development in Pakistan and that the effect of corruption on financial development in Pakistan is negative from the ECM result. The ramifications of this finding are that economy cannot develop quickly without zero resilience in corruption. At last, the investigation bolster past outcomes in the writing of the impact of corruption on monetary development (Dr. Nwankwo \& Odi , 2014). Based on above previous studies the alternative hypothesis has been developed:

H2: There is significant impact of foreign borrowings on real exchange rate.

\section{Empirical Methodology}

\subsection{Data}

This study is based on secondary data and we have collected the data from Pakistan Economic Survey, Transparency International US and World Bank economic indicators. All data sets used in this study are from 2002 to 2016.

Sukkur IBA Journal of Management and Business - SIJMB | Volume 6 No. 1 January - June 2019 @ Sukkur IBA University 
Table I: Secondary Data

\begin{tabular}{|c|c|c|c|c|c|c|}
\hline \multirow[t]{2}{*}{ Year } & \multicolumn{2}{|c|}{ Corruption Perception Index } & \multicolumn{2}{|c|}{ Foreign Borrowings } & \multicolumn{2}{|c|}{ Real Exchange Rate } \\
\hline & $\begin{array}{l}\text { Pakistan } \\
\text { (percentage) }\end{array}$ & $\begin{array}{l}\text { India } \\
\text { (percentage) }\end{array}$ & $\begin{array}{l}\text { Pakistan } \\
\text { (Pak rupees, } \\
\text { million) }\end{array}$ & $\begin{array}{l}\text { India } \\
\text { (Indian } \\
\text { rupees, } \\
\text { million) }\end{array}$ & $\begin{array}{l}\text { Pakistan } \\
\text { (Exchange } \\
\text { rate in US } \\
\text { dollar) }\end{array}$ & $\begin{array}{l}\text { India } \\
\text { (Exchange } \\
\text { rate in US } \\
\text { dollar) }\end{array}$ \\
\hline 2002 & 2.6 & 2.7 & 99,000 & -119.3 & 58.5 & 48.0 \\
\hline 2003 & 2.5 & 2.8 & 63,900 & -134.9 & 57.2 & 45.6 \\
\hline 2004 & 2.1 & 2.8 & 124,690 & 147.5 & 59.1 & 43.6 \\
\hline 2005 & 2.1 & 2.9 & 96,573 & 74.7 & 59.8 & 45.1 \\
\hline 2006 & 2.2 & 3.3 & 176,316 & 84.7 & 60.9 & 44.2 \\
\hline 2007 & 2.4 & 3.5 & 230,353 & 93.2 & 61.2 & 39.4 \\
\hline 2008 & 2.5 & 3.4 & 625,858 & 110.2 & 79.1 & 48.5 \\
\hline 2009 & 2.4 & 3.4 & 530,756 & 110.4 & 84.3 & 46.7 \\
\hline 2010 & 2.3 & 3.3 & 740,172 & 235.6 & 85.7 & 44.8 \\
\hline 2011 & 2.5 & 3.1 & $1,086,704$ & 124.5 & 90.0 & 53.3 \\
\hline 2012 & 27 & 36 & $1,632,084$ & 72.0 & 97.1 & 54.8 \\
\hline 2013 & 28 & 36 & $1,835,540$ & 72.9 & 105.7 & 61.9 \\
\hline 2014 & 29 & 38 & 876,992 & 129.3 & 100.5 & 63.3 \\
\hline 2015 & 30 & 38 & $1,275,693$ & 127.5 & 104.9 & 66.3 \\
\hline 2016 & 32 & 40 & 978,858 & 148.7 & 104.8 & 68.0 \\
\hline
\end{tabular}

\subsection{Model Specification \& Variables}

Whereas,

$$
\mathrm{RER}=\beta_{0}+\beta_{1} \mathrm{CPI}+\beta_{2} \mathrm{FB}+\mathcal{E}(\mathbf{1})
$$

$\beta_{0=}$ Constant Value

RER= Real Exchange Rate

CPI= Corruption Perception Index

$\mathrm{FB}=$ Foreign borrowings

$\mathcal{E}=$ Error Term

\subsection{Unit Root Test}

It has been practically observed that the time series data is non-stationary in many cases due to increasing trends in data. If, OLS regression is being applied on nonstationary data findings to be considered by research scholars more an overestimated than the actual once. Augmented Dickey-Fuller (ADF) test usually is applied on individual variable on various levels such as level, 1st difference and 2nd difference until null hypothesis is rejected with assumption that data is stationary. It is highly recommended by the researcher before applying in the OLS regression on research model that the data should be checked for stationary.

To study the test of stationary on time series data, we have applied Augmented Dickey-fuller (ADF). The ADF is based on the following equation:

$$
\Delta \mathbf{Y}_{\mathrm{t}}=\alpha_{0}+\alpha_{1} \mathbf{Y}_{\mathrm{t}-1}+\sum_{\mathrm{j}=1}^{\mathrm{k}} \mathbf{d}_{\mathrm{j}} \Delta \mathrm{Y}_{\mathrm{t}-1}+\varepsilon_{\mathrm{t}}
$$

Sukkur IBA Journal of Management and Business - SIJMB | Volume 6 No. 1 January - June 2019 @ Sukkur IBA University 
Where er is pure white noise error, difference operator $\mathrm{D}$ is first, $\mathrm{Y}_{\mathrm{t}}$ is a variable with time $\mathrm{t}, \mathrm{a} 0$ is the taken as constant and whereas $\mathrm{k}$ is the optimum numbers of lags for the dependent variable. The test of ADF provides cumulative distribution of statistics. The variable will be considered stationary when value of coefficient is less than critical value (Dicky and Fuller, 1979).

\subsection{OLS Regression Analysis}

The ordinary least squares regression (OLS) is the statistical technique used for data analysis which is commonly known as a linear regression. In this analysis it is used to apply for measuring the relationship between dependent variable and more than one independent variable. In this study there are three independent variables such as corruption perception index and foreign borrowings, one dependent variable real exchange rate.

\section{Results and Discussion 4.1 Panel Unit Root Test}

Table II: Augmented Dickey-Fuller test statistic (Panel Unit Root Test)

\begin{tabular}{lll}
\hline Variable & $\begin{array}{l}\text { P-value at } \\
2^{\text {nd }} \text { difference }\end{array}$ & $\begin{array}{l}\text { Decision rule for rejection } \\
\text { of null hypothesis p-value } \\
\text { less than 0.05 }\end{array}$ \\
\hline $\begin{array}{l}\text { Log Real Exchange Rate } \\
\text { (Dependent variable) }\end{array}$ & $0.0031 * *$ & $\begin{array}{l}\text { Rejected null hypothesis } \\
\text { (Data is stationary) }\end{array}$ \\
$\begin{array}{l}\text { Log Corruption Perception } \\
\begin{array}{l}\text { Index (Independent } \\
\text { variable) }\end{array}\end{array}$ & $0.0029 * *$ & $\begin{array}{l}\text { Rejected null hypothesis } \\
\text { (Data is stationary) }\end{array}$ \\
$\begin{array}{l}\text { Log Foreign Borrowing } \\
\text { (Independent variable) }\end{array}$ & $0.0489 * *$ & $\begin{array}{l}\text { Rejected null hypothesis } \\
\text { (Data is stationary) }\end{array}$ \\
\hline
\end{tabular}

To examine the time series data of this study, we applied Augmented Dickey-Fuller (ADF) panel unit root test. The test was applied after taking log variable at 2 nd difference. Table 2 indicates the result of panel unit root test. This table 2 raveled that Augmented Dickey-Fuller test statistic that all studied variables are stationary at level of 2 nd difference at level real exchange rate, corruption perception index and foreign borrowings after taking log of variables. As results suggest that data is stationary, now we can apply OLS panel regression on our dependent and independent variables and findings would not be overestimated.

Sukkur IBA Journal of Management and Business - SIJMB | Volume 6 No. 1 January - June 2019 @ Sukkur IBA University 


\subsection{Panel OLS Regression (Fixed effect Model)}

Table III: Panel Least Square Method (OLS)

\begin{tabular}{lllll}
\hline $\begin{array}{l}\text { Independent } \\
\text { variables Variable }\end{array}$ & P-value & R-value & Beta value & $\begin{array}{l}\text { Decision rule for } \\
\text { rejection of null } \\
\text { hypothesis p-value } \\
\text { less than } 0.05\end{array}$ \\
\hline $\begin{array}{l}\text { Log Corruption } \\
\text { Perception Index }\end{array}$ & $0.0000^{* *}$ & & 0.128317 & $\begin{array}{l}\text { Rejected null } \\
\text { hypothesis } \\
\text { (Significant } \\
\text { impact) } \\
\text { Rejected null } \\
\text { hypothesis } \\
\text { (Significant } \\
\text { impact) }\end{array}$ \\
\hline $\begin{array}{l}\text { Log Foreign } \\
\text { Borrowing }\end{array}$ & $0.0000^{* *}$ & $90.83 \%$ & & \\
& & 0.059397 & & \\
\hline
\end{tabular}

There are two methods such as fixed effect model and random effect model are applied on panel data. In order to decide which method is appropriate, we applied Hausman test. The results from Hausman test revealed that the fixed effect model is appropriate for this study. Results obtained from fixed effect model are indicated in table 3. A panel least square method table shows three important values, $\mathrm{p}$-value, Rvalue and value of beta. P-value shows level of significance and value of beta usually determines the relationship between dependent variable with independent variables. The R-value determines overall fitness of model in percentage. In this study that the variable all studied variables such as Log Corruption Perception Index, and log foreign borrowing is found to have positive and significant impact with dependent variable real exchange rate. This model is fit $90.83 \%$ that means our independent variables explain to dependent variables in terms of percentage.

The exchange rate is highly unstable in the context of developing countries, the empirical findings of this study revealed that corruption is also one the key reason in developing countries such as Pakistan and India for such behavior. Corruption in government or state owned department devaluate the currency of studied countries which may create serious problems such as negative balance of payment and burden of foreign borrowings. Studied developing countries are not self-sufficient in terms revenue and expenditures. They always look for external or foreign borrowings. However, empirical results of this study indicated that higher foreign borrowings also destabilize currency of country so, country based options should be taken into consideration.

Log RER = 3.381700+ 0.128317 log corruption perception index $+\mathbf{0 . 0 5 9 3 9 7} \log$ foreign borrowing

Sukkur IBA Journal of Management and Business - SIJMB | Volume 6 No. 1 January - June 2019 @ Sukkur IBA University 


\section{Conclusion and Policy Implication}

The main purpose of this study was to find the impact of measuring the economic cost of exchange rate from Pakistan and India. Secondary data has been analyzed from 2002-2016 in E-view versions 7 through panel unit root test and panel OLS regression. Results indicated that variable all studied variables such as Log Corruption Perception Index, and log foreign borrowing is found to have positive and significant impact with dependent variable real exchange rate. Unique findings of this study is that exchange rate within country create two serious problems for the whole economy such as the level of corruption in government department increased and amount of foreign borrowings also tends to enhanced. The fluctuation of exchange rate needs to addressed at government level. Based on these results it is highly recommended that the government should take certain corrective actions in order to stable the exchange in both countries Pakistan and India. Transparency among the government departments should be developed in order to avoid corruption in stated owned departments.

The empirical findings from this study can be considered for future policy making in studied countries such as Pakistan and India. Both issues the corruption in government departments and foreign borrowings are serious in nature that impact on exchange rate. Therefore, the regulatory authorizes such as State Bank or central Bank of both countries Pakistan and India along with government should design polices for stable exchange rate of respective countries.

\subsection{Future Research}

- This study can be extended to other developing countries like Bangladesh and South Asian countries.

- A comparative analysis can be done between Pakistan and its nearby countries such as Bangladesh and Sir Lanka.

\section{References:}

Agenor, P. R., Bhandari, J. S., \& Flood, R. P. (1992). Speculative attacks and models of balance of payments crises. Staff Papers, 39(2), 357-394.

Atique, R., \& Malik, K. (2012). Impact of domestic and external debt on the economic growth of Pakistan. World Applied Sciences Journal, 20(1), 120-129.

Corsetti, G., Pesenti, P., \& Roubini, N. (1999). What caused the Asian currency and financial crisis? Japan and the world economy, 11(3), 305-373.

Flood, R. P., \& Garber, P. M. (1984). Collapsing exchange-rate regimes: some linear examples. Journal of international Economics, 17(1-2), 1-13.

Frankel, Jeffrey A., and Andrew Rose. 1996. Currency crashes in emerging markets: An empirical treatment. Journal of International Economics 41 (3-4): 351-66.

Ghosh, S. R., \& Ghosh, A. R. (2003). Structural vulnerabilities and currency crises. IMF Staff Papers, 50(3), 481-506.

Sukkur IBA Journal of Management and Business - SIJMB | Volume 6 No. 1 January - June 2019 ๑ Sukkur IBA University 
Krugman, P. (1979). A model of balance-of-payments crises. Journal of money, credit and banking, 11(3), 311-325.

McKinnon, R. I., \& Pill, H. (1997). Credible economic liberalizations and overborrowing. The American Economic Review, 87(2), 189-193.

McKinnon, R. I., \& Pill, H. (1998). International overborrowing: a decomposition of credit and currency risks. World Development, 26(7), 1267-1282.

McKinnon, R. I., \& Pill, H. (1999). Exchange-rate regimes for emerging markets: moral hazard and international overborrowing. Oxford review of economic policy, 15(3), 19-38.

McKinnon, R. I., \& Pill, H. (1999). Exchange-rate regimes for emerging markets: moral hazard and international overborrowing. Oxford review of economic policy, 15(3), 19-38.

Miyakoshi, T. (2000). The causes of the Asian currency crisis: empirical observations. Japan and the World Economy, 12(3), 243-253.

Obstfeld, M. (1984). Rational and self-fulfilling balance-of-payments crises.

Radelet, Steven, and Jeffrey Sachs. 1998. The East Asian financial crisis: Diagnosis, remedies, and prospects. Brookings Papers on Economic Activity, 1(1).

Rodrik, D., \& Velasco, A. (1999). Short-term capital flows (No. w7364). National bureau of economic research.

Rose, A. K., \& Wyplosz, C. (1996). Contagious currency crises: first tests. Scandinavian Journal of Economics, 98(4), 463-84.

Uddin, K. M. K., Rahman, M. M. \& Quaosar, G. M. A. A. (2014). Causality between exchange rate and economic growth in Bangladesh. European Scientific Journal, 10(31): 11-26.

Wei, S. J., \& Wu, Y. (2002). Negative alchemy? Corruption, composition of capital flows, and currency crises. In Preventing currency crises in emerging markets 461506). University of Chicago Press.

Wei, S. J., \& Wu, Y. (2002). Negative alchemy? Corruption, composition of capital flows, and currency crises. In Preventing currency crises in emerging markets (pp. 461-506). University of Chicago Press.

Sukkur IBA Journal of Management and Business - SIJMB | Volume 6 No. 1 January - June 2019 @ Sukkur IBA University 